\title{
Problems and Countermeasures of River Management in the Process of Rapid Urbanization in China
}

\author{
Ziyang Zhao ${ }^{1,2}$, Hongrui Wang ${ }^{1,2, *} \mathbb{D}$, Yuanyuan Zhang ${ }^{1,2}$, Caiyun Deng ${ }^{1,2}$, Qiong Xie ${ }^{1,2}$ \\ and Cheng Wang ${ }^{3}$ \\ 1 College of Water Sciences, Beijing Normal University, Beijing 100875, China; zyzhao@mail.bnu.edu.cn (Z.Z.); \\ 201831470019@mail.bnu.edu.cn (Y.Z.); dengcaiyun@mail.bnu.edu.cn (C.D.); \\ xieqiong1985@hotmail.com (Q.X.) \\ 2 Beijing Key Laboratory of Urban Hydrological Cycle and Sponge City Technology, Beijing 100875, China \\ 3 Environment Science Division, Argonne National Laboratory, Lemont, IL 60439, USA; \\ chengw@knights.ucf.edu \\ * Correspondence: henrywang@bnu.edu.cn; Tel.: +86-10-5880-7941
}

Received: 2 July 2020; Accepted: 7 August 2020; Published: 12 August 2020

check for updates

\begin{abstract}
The rapid process of urbanization has led to water pollution, reduction of space areas and channel deposition. However, current river protection and management levels are not suitable for city development level and human demand. Therefore, these problems have not yet been solved. China is still in an era of rapid urbanization, which means that the influence of urbanization in rivers will increase in the future-and the task of river protection and management will be more arduous. In order to meet the challenges and opportunities brought by urbanization and promote the sustainable use and management of river, this study puts forward relevant suggestions on river protection and management, such as river management mechanisms, economic incentive instruments, technical support, transformation of development concepts, improving laws, regulations and policies and stimulating public participation.
\end{abstract}

Keywords: urbanization; river management; river function; China

\section{Introduction}

China is one of the countries with the most rivers in the world. There are many great rivers with a long history in China, of which there are more than 2000 rivers with a basin area over $1000 \mathrm{~km}^{2}$ and about 45,200 rivers with a basin area over $500 \mathrm{~km}^{2}$ (Figure 1) [1]. From time immemorial, people have realized that rivers make great contributions to human existence and development [2]. Cities-as the place of population gathering and economy humming - are mostly distributed near large rivers, thus, they are more closely related with the river $[3,4]$. The river has many functions, such as water supply, flood discharge, shipping and ecological service $[5,6]$. The diversity of its function determines that river will play an increasingly important role in urban development.

Urbanization refers to the transformation from a rural to an urban way of life [7]. According to the characteristic of its speed, urbanization is divided into four phases in China: starting phase (1949-1957), stagnation phase (1958-1978), steady development phase (1979-1996) and fast development phase (after 1996) [8]. Importantly, based on a comparison of spatial metrics between China (developing country) and other developed countries, urban agglomeration in China is more compact and dense [9]. With the acceleration of urbanization and the rapid development of social economy in China, sustainable use of rivers is seriously threatened and challenged. Changes in population structures have brought about transformations of landscapes, which have had many serious impacts on river ecosystems. Generally speaking, the increase of impervious surface coverage in cities changes the hydrology and 
topography of rivers, which will lead to changes in river habitats. In addition to impermeability, urban surface runoff has increased the load of nutrients, metals and pesticides due to urban and industrial emissions. These changes have caused the process of river ecosystems to be affected by urbanization [10]. Moreover, previous studies show that urban areas are becoming increasingly subject to and vulnerable to water-related natural disasters [11]. Natural water disasters can have huge social and economic impacts on megacities; they are part of a general upward trend in hydrological disasters affecting urban areas and cities' vulnerability to water-related risks [12,13]. In the accelerating phase of urbanization in China, these problems are more prominent, which have affected the normal development and use of rivers and become the bottleneck of urban development [14,15]. A series of problems brought about by urbanization have put forward higher requirements for river protection and management. However, the level of river protection and management does not adapt to the increasing demand of river function, making these problems become more prominent. If these problems cannot be solved effectively, they will bring adverse effects to urban development and even become an important factor restricting urban development. Therefore, study on effect of urbanization is very important for sustainable development of rivers.

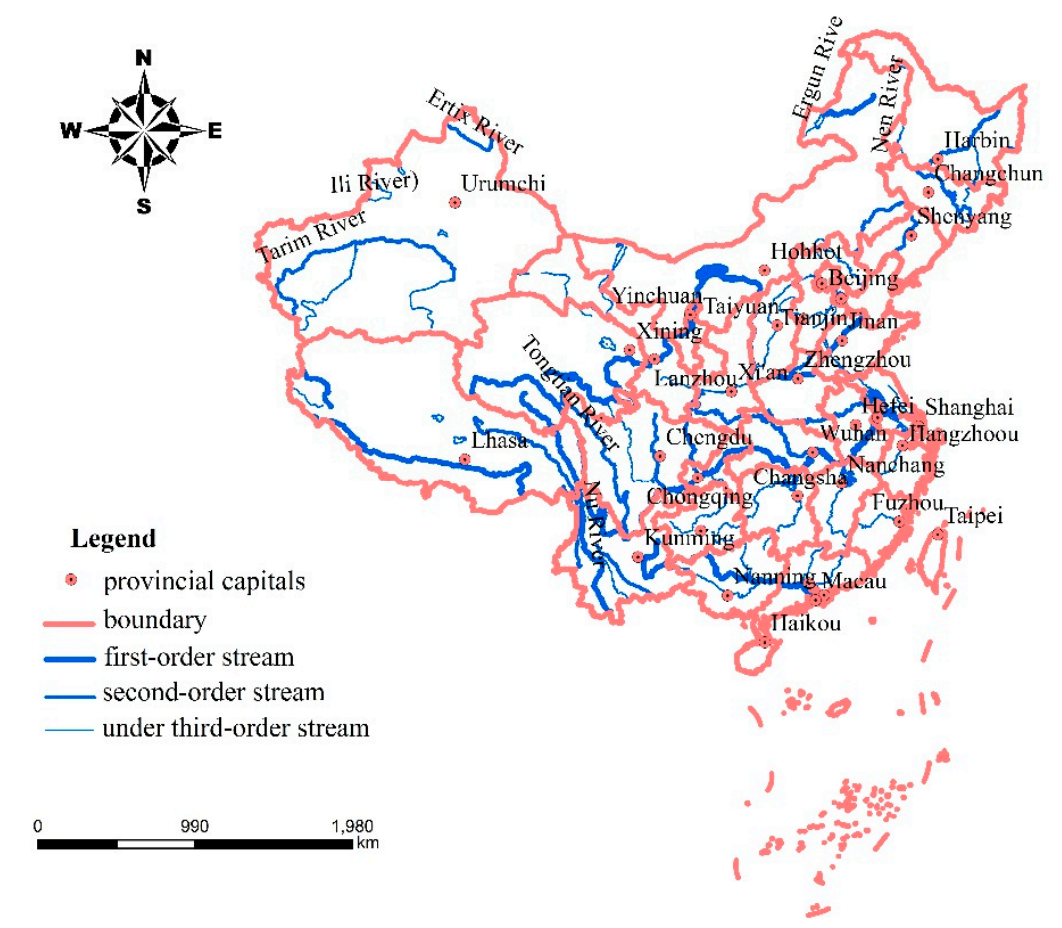

Figure 1. Distribution map of the main rivers in China.

In order to address the severe situation brought by rapid urbanization and promote the sustainable use and management of rivers, it is necessary to attach more importance to study on the comprehensive function of urban river. This study analyses the urban development, design the questionnaire and explore the detrimental effects of urbanization to river. On this basis, summarize the problems existing in river protection and management and then put forward comprehensive countermeasures.

\section{Urbanization Development Level}

In the past, the quantitative indicators of urbanization mostly focused on the changes of urban population, however, with its connotation increasing, urbanization indicates not only the quantitative change of cities and urban population, but also the impact of the economy, urban forms and land use $[16,17]$. Therefore, the main characteristics of urbanization are the increase of urban population, the development of non-agricultural economy and the expansion of urban land. We select three indicators, including population urbanization level $(\mathrm{Up}$, the ratio of urban population to total 
population), economic urbanization level (Ue, the ratio of non-agricultural GDP to total GDP) and spatial urbanization level (Us, the ratio of urban land area to total area, of which urban land area includes area of urban and designated town) to describe urbanization development level. As shown in Figure 2, from 2000 to 2018, Up, Ue and Us have increased at an average rate of $3.12 \%, 0.25 \%$ and $4.20 \%$ per year, respectively.

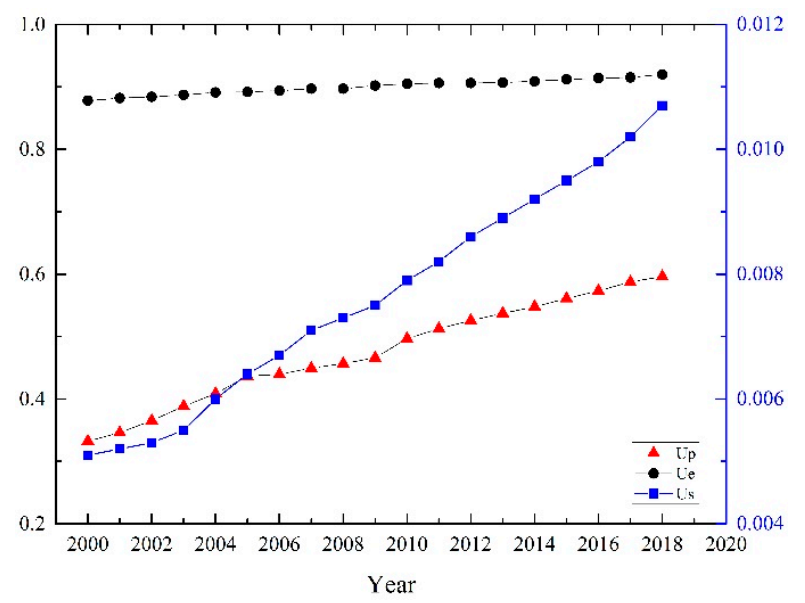

Figure 2. Changes of urbanization development level in China from 2000 to 2018.

With the deep propel of urbanization, problems brought by exclusive urban construction and narrow pursuit of GDP growth regardless of environmental carrying capacity becomes increasing obvious [18]. In addition, lack of foresightedness in urban planning and poor execution lead to incoordination of urbanization development among different regions, thus, waste of resources, deterioration of environment and other issues that need to be solved [19]. Among which, the impact on water resources is especially prominent. Some studies have indicated that drainage density, surface water ratio, water quality parameters, floods, river fragmentation and other indicators of river systema are in high correlation with urbanization [20-23]. To date, most cities in China are still in the accelerating stage of urbanization. According to the National New Urbanization Plan, it is expected that the population urbanization level will increase to $60 \%$ in 2020. By then, the urban population of China will increase by nearly 100 million people, which will set higher demands for water supply security, flood control and water environment regulation. River, regarded as the symbols of a city, is an important part of urban environment. Therefore, the task of river protection and management will be more arduous and even become a great challenge in the process of rapid urbanization.

\section{Effect of Urbanization on River}

Under the background of rapid urbanization and science and technology developing, river function is also evolving. Specifically, the functions of urban river can be summarized as follows (Figures 3 and 4) [24-26]: (1) hydrological function, which has nothing to do with human activities, includes water storage, water delivery and substance circulation and energy exchange; (2) ecological function, which can be divided into habitat function, corridor function and water quality purification function according to different ecological benefits; (3) social service function, including urban water supply, flood control, power generation, shipping, fishery breeding and landscape function. With the increase of urbanization's demand for river functions, the use pressure of urban rivers and the intensity of human interference continue to increase, which affects effects of river comprehensive function and even lead to a function decline in some areas. 


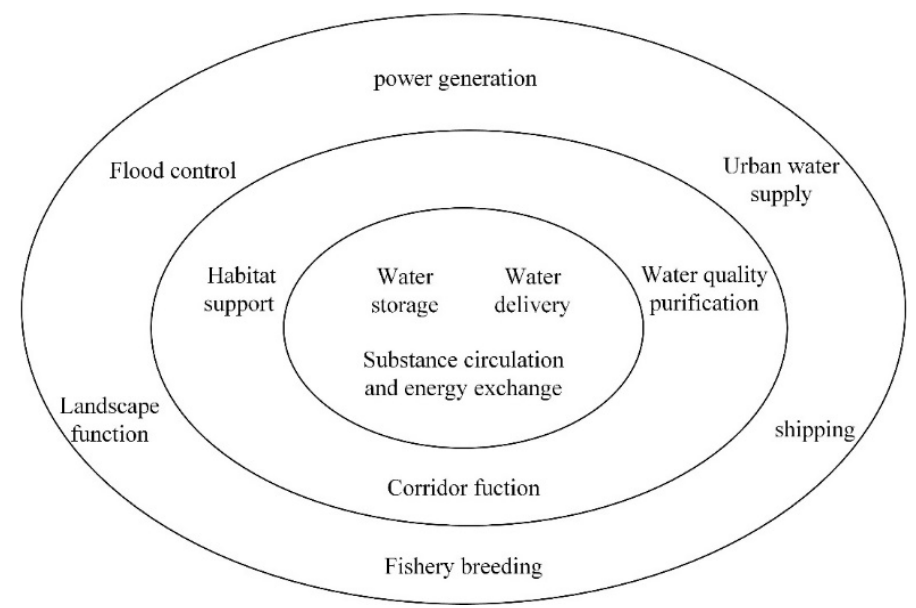

Figure 3. Classification of urban river function.

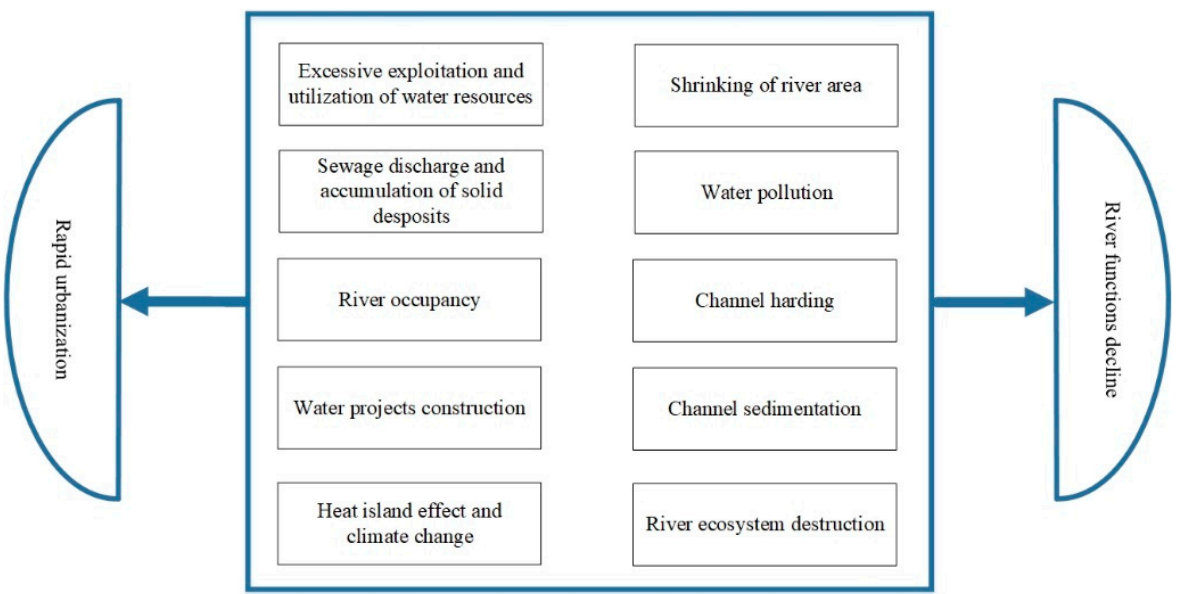

Figure 4. Effect of urbanization on rivers.

\subsection{Shrinking of River Area}

According to the Bulletin of First National Census for Water issued by the Ministry of Water Resources and the National Bureau of Statistics of the People's Republic of China in 2013 [1], there are only about 23,000 rivers in China with a basin area over $100 \mathrm{~km}^{2}$, which is $40 \%$ lower than that before 2013. The reduction of rivers coincided with the period of rapid urbanization; thus, urban development is considered to be an important cause. The surface water ratio is an important parameter to characterize the variation of river spatial range, which refers to the proportion of the area of rivers and lakes to the total area of the administrative region. Studies have shown that, river land is being encroached and river spatial range is reducing with the area of urban commercial district, road traffic and river engineering facilities expanding gradually, so the surface water ratio is inversely proportional to indicators of urbanization $[27,28]$. Moreover, this reflects that the urbanization process is not fully coordinated with the protection of the river network structure [29]. Taking Shanghai as an example, in the process of economic and social development, the river network is destroyed and the surface water ratio shows the downtrend. From the early 1980s to the end of the last century, the surface water ratio of Shanghai had come down from $11.1 \%$ to $8.4 \%$, which means that rate of decline is about $25 \%$. Enter the 21st century, Shanghai is adopting tighter control on water resource protection, easing the situation, however, rally of the surface water ratio is still difficult. 


\subsection{Water Pollution}

According to China statistical yearbook from 2010 to 2018 (Figure 5), the discharge of sewage show a rise in most provincial capitals, except Yinchuan, Urumqi, Harbin and Xining. Reduction of industrial sewage could be due to the implementation of the sewage charge, the improvement of wastewater treatment efficiency and recycled water utilization. Among them, the growth rate of domestic sewage discharge in Xi'an and Guiyang is more than 100\%, while the ratio to total sewage discharged has increased greatly. Moreover, sewage discharge in areas with higher urbanization level, including Shanghai, Beijing, Guangzhou, Chongqing, Hangzhou and Shanghai.

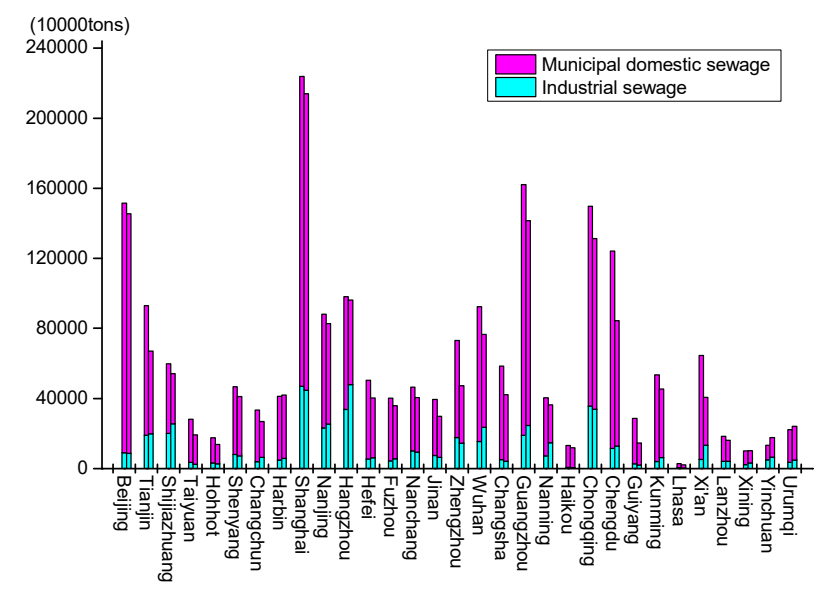

Figure 5. Comparison of sewage discharge between 2010 and 2018 from each provincial capital in China.

The discharge of industrial and domestic sewage continuously increases with rapid industrialization and urbanization. However, the lag of construction of sewers and sewage treatment facilities in urban areas leads to industrial and domestic sewage being discharged directly into the river, causing deterioration of water quality and aggravated eutrophication. In addition to traditional pollution sources, river is also polluted by other pollutants, such as oil pollutants leaked by ships in navigable watercourses and solid waste dumped along the river. On one hand, the urban river faces the pressure of increasing pollutant quantity. On the other hand, the pollution types are increasingly complicated, which makes it more difficult to manage and protect urban river.

According to the China environmental state bulletin in 2016 and China environmental quality standards for surface water in 2002 issued by the Ministry of Environmental Protection [30], among the monitoring stations of ten major watersheds in China, 9.1\% are seriously polluted (up to Grade V water quality), and the most polluted rivers and lakes are distributed in cities. In addition to domestic sewage, high concentrations of $\mathrm{Hg}$, volatile phenols are also having an impact on urban river. The water quality in Shanghai from 2001 to 2015 is shown in Figure 6 Since 2001, the water quality of rivers in the city has been seriously polluted and there is no river up to Grade I surface water standard, meanwhile, the proportion of rivers under Grade V has increased significantly. From 2004 to 2007, the river up to Grade V and under Grade V even accounted for nearly 70\%. Although the condition started improving in 2007, there is still a large gap compared with the level in 2001. The natural river has been deeply affected by human activities.

\subsection{Channel Hardening}

In the urban construction in recent years, human intervention has become increasing serious, which has changed its natural form [31]. Channel hardening is an important measure that paving natural riverbed with concrete slabs or boulders in water conservancy projects. Since the 1980s, channel hardening has been used for river regulation in many cities, which is considered as the measure beneficial to urban flood control and economization on land. However, in the long run, impacts of 
channel hardening on human and cities is more negative than positive [32]. On one hand, channel hardening prevents the river from leaking, which will reduce groundwater recharge, affect the urban water supply and make the urban water shortage more serious. Meanwhile, it could isolate the link between the aquatic and terrestrial ecosystem, causing rivers to evolve independently. The habitats are destroyed, and river function is weakened accordingly.

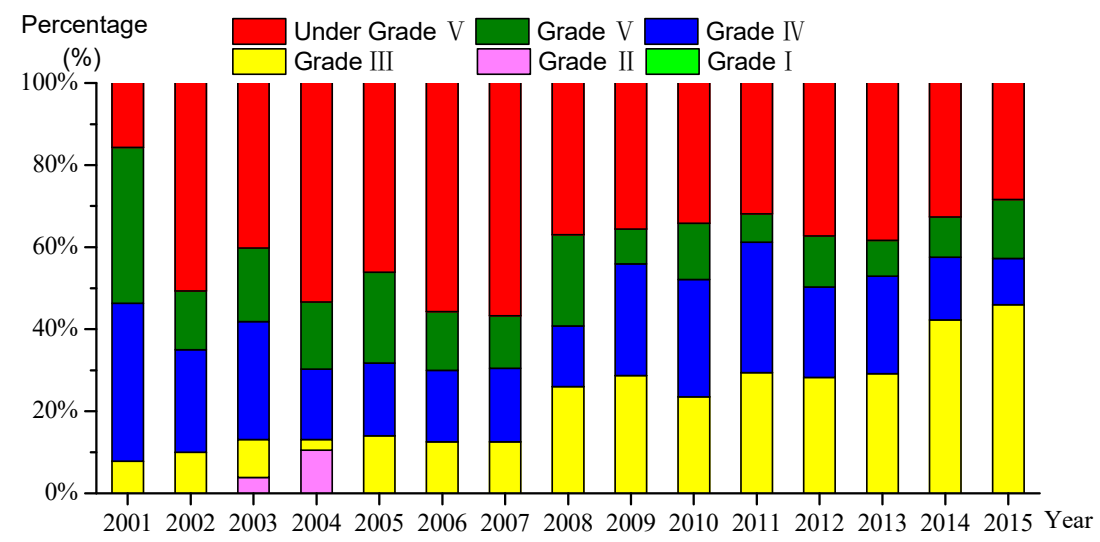

Figure 6. Water quality of inland rivers in Shanghai from 2001 to 2015.

Since the 1990s, many developed countries, including Germany, the United States and Japan extensively dismantled hard materials laid on river beds before. In fact, the cost of removing lining is much more expensive than paving, but these countries generally believe that preserving the natural nature river is essential to protect animal and plant resources. In recent years, with enhancing consciousness of protecting ecological environment, demolition work has begun in Beijing and some other cities. However, it will take some time to dismantle nationally.

\subsection{Severe Channel Sedimentation}

To date, a large number of water conservancy and hydropower projects in our country are constructed, and the river channel sedimentation has become a prominent problem in its operation and maintenance. The wading engineering has changed runoff mode of the urban stream, the water gate intercepts the upstream water, and the sediment particles are deposited in front of the dam. Moreover, buildings along the banks, wharfs, ships can cause parts of rivers deposited. Simultaneously, due to the increase in diverted water volume and irrigation water on urban river, runoff in the upstream decreases and waste increases, thus, making the river continuously silt up and reduce its flood control function [33,34]. Taking Shenzhen as an example, the rivers in Shenzhen are distributed in the five major watersheds, four major bay and 151 rivers in planning, in which varying degrees of siltation exist. It is estimated that the total amount of silt in the whole city is as high as 55 million cubic meters. Among them, the sediment deposition of the main stream of the Maozhou River is very serious. Volume of sediment deposition in Weilu section was up to 4.8 million cubic meters, and the average sediment thickness is $2-3 \mathrm{~m}$. The total amount of sedimentation in the Shenzhen River is about 4.15 million cubic meters, and the accumulated sediment thickness for 8 years of the main channel is $0.49 \mathrm{~m}$. The siltation not only affects the navigation and flood discharge capacity of the river, but also affects the ecological function.

\subsection{River Ecosystem Destruction}

There are two main reasons for the destruction of urban river ecosystems, one is the internal heat island effect [35], and the other is the external climate change [36]. The phenomenon of urban heat island means that the air temperature in urban areas is higher than that in nearby non-urban areas [37]. The increase in air temperature is mainly due to the thermal storage capacity of urban building materials, the interruption of the energy transfer process (i.e., airflow), and the change in evapotranspiration rate 
caused by highly impervious surfaces [38]. As the urban water system absorbs and stores additional heat in spring and summer, the increase in air temperature in the non-urban-to-urban gradient is also the cause of the increase in water temperature [39]. Although the sensitivity of water temperature to air-temperature rise varies from season to season, the increase in air temperature is usually the main driving force for the increase in water temperature [36]. Regarding external climate changes, it is expected that the earth will experience relatively rapid changes in temperature and precipitation this century, which is mainly due to the increase in the concentration of greenhouse gases in the atmosphere caused by human activities [36]. This change has a more significant impact on urbanization. Changes in temperature and precipitation may have a significant impact on the temperature and hydrology of the urban water system, which in turn affects species that adapt to specific hydrological systems, water temperatures and related physical characteristics of aquatic habitats $[40,41]$.

\section{Problems in River Management System}

The river faces many problems, such as water pollution, siltation and channel hardening [42-45]. The level of river protection and management does not adapt to the increasing demand of river function, making these problems become more prominent. If these problems cannot be solved effectively, they will bring adverse effects to urban development and even become an important factor restricting urban development.

\subsection{Unclear Management Functions}

In china, fragmentation exists between management of water resources and water environment. Although the Water Conservancy departments are responsible for integrated management, river management also involves other departments such as Environmental Protection, Transportation and Forestry Departments (Figure 7). In this case, the differentiation of stakeholder and conflicts of interests lead to ineffective river management. In addition, there is no obvious cut division of the terms of reference and the degree of responsibility of various departments. As a result, the functions of various departments overlap and the relationship of interests is complicated cause low management efficiency [46-49].

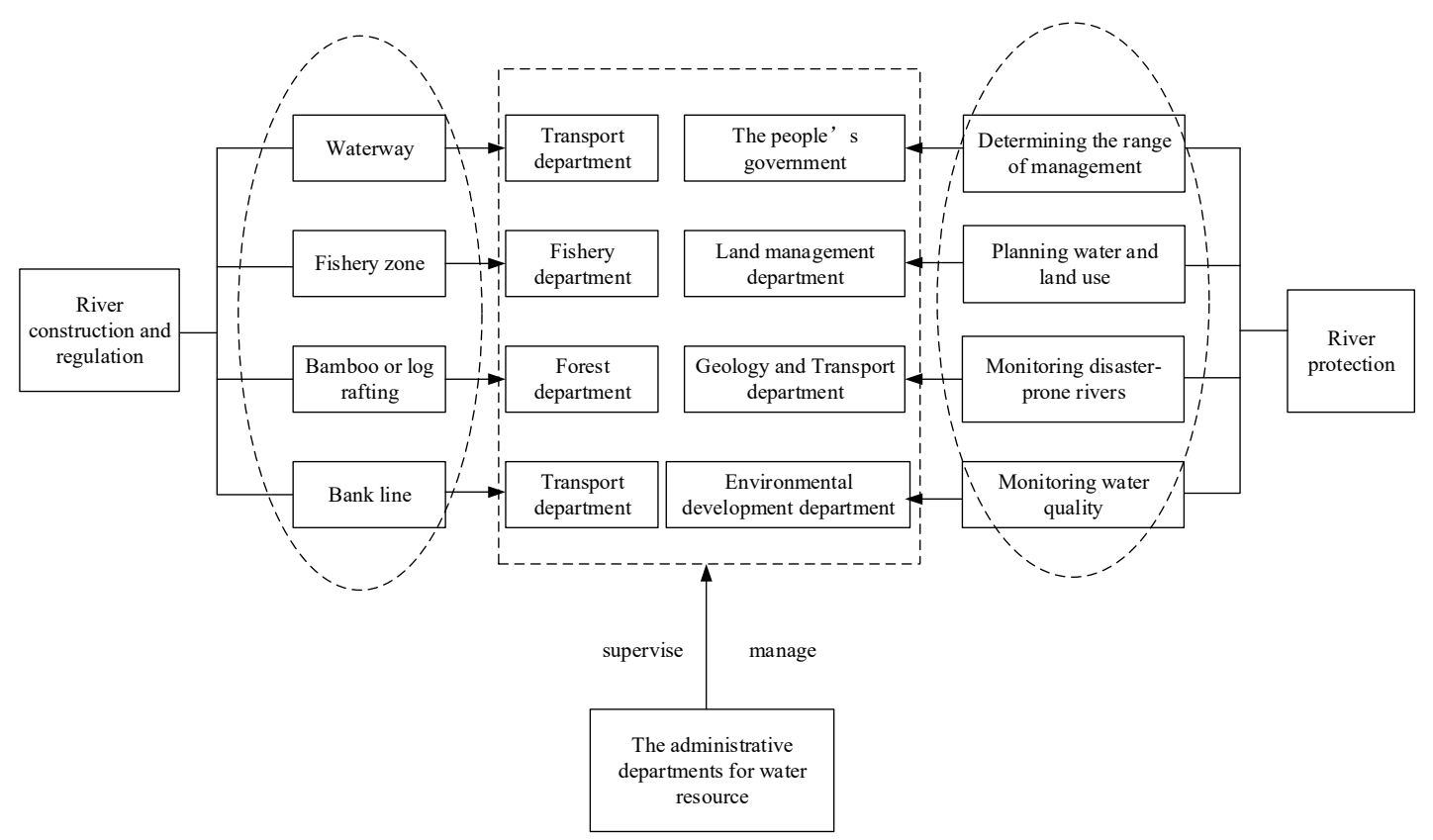

Figure 7. Management system of river management and protection. 
In general, Water Conservancy Departments are responsible for water resources protection and Environmental Protection Departments are responsible for water pollution prevention. However, in the practical work, the two parts involves in two departments. For example, in protection of water quality, environmental protection departments are responsible for water environmental monitoring, statistics and information publishing and the water conservancy department is working on the same things, which will not only lead to duplication of work, but also lead to different data versions. Therefore, the division of departments results in some conflicts of interest, and it is difficult to form an efficient and comprehensive decision-making mechanism of river management.

\subsection{Imperfect Planning System}

Before the 1980s, the problems related to river were not prominent, so there were fewer policies and regulations related to river management. Along with its progress in reform and opening up, urban economy is advancing by leaps and bounds, and the river is facing much more problems such as flood, drying up and water pollution, which has aroused public great concern [50,51]. Therefore, China has increased its input in river management, relevant policies and regulations have been preliminarily established. The law on prevention and control of water pollution, the water law and the flood control law cover all aspects of environmental protection, water pollution prevention, water resources management and flood control.

The special law, which refers to Regulations of river administration of the People's Republic of China, promulgated by the State Council in 1988, have played a positive role in promoting the development of river. However, its provisions are mainly based on given management system and flood protection, and lack of regulation on ecological protection, which are not suitable for the multifunction and management demand of rivers.

On account of limitations of laws and regulations on the national level, some cities have established local regulations to meet the needs of local river management. However, a considerable number of cities have not yet formulated or issued river management policies, and the relevant laws and regulations still need to be further improved. On the whole, the planning of urban river management lags behind the actual river development, which leads to many problems including disorderly occupation of river land and severe water pollution in the process of urban construction.

\subsection{Ignore the Coordinated Development of River Functions}

Urban River, including many kinds of functions such as water supply, flood control, shipping, ecological function to maintain urban ecosystem and economy stable, may cause the river out of balance and stability. Therefore, different functions should complement and reinforce each other and develop at the same pace. However, in current process of urbanization, the local government attaches too much importance to the growth of GDP and maximize the function that is directly related to economic development, which leads human interference with natural river course to a larger range and deeper degree. From the angle of ecology, wading engineering affects the ecological system of river. For a long time, administrative departments care more about direct service function than ecological protection and then affects the performance of comprehensive functions [46,47].

\subsection{Imbalance in Management Level}

In recent years, with the construction of ecological civilization, the idea of low impact development (LID) has been applied in river management, especially in developed areas [50,52-55]. The concept of "sponge city" originated from low-impact development and river is an indispensable part of the sponge city construction [56].

Pilot projects for "sponge city" have been started in Beijing, Tianjin, Shanghai, Shenzhen, etc. Much time, energy and financial resources are invested to improve the water quality in relatively developed areas. The management system is more mature and effective, and the environmental index are gradually brought into the urban evaluation system. However, river management in small cities and 
economic backward areas is neglected. Moreover, the current management level of local management personnel is still relatively backward, and the concept of urban planning and management is far behind the objective needs of urban development, resulting in a series of problems to be solved, such as serious water pollution and artificial seizure of river courses. These problems are the difficulties in improving river management especially in some small cities with high industrialization. These cities could be the breakthrough in reforming our river governance system. Therefore, in addition to major cities, river management mechanisms in small cities and economic backward areas should be strengthened to avoid the short board effect and then affect the overall development of river management.

Taking Nanjing as an example, Nanjing has a long and horizontal river network with abundant water systems. However, with the development of the city, the river network has been intermittent and rapid population growth has exacerbated water pollution. To date, nearly 70 percent of the rivers in Nanjing are malodorous and black. Although since 2009, the city has made the treatment of malodorous and black river a priority, effective measures are lacked in river management. Then, it is difficult for all departments and citizens to work together. In general, in terms of river management and regulation, large cities are better than small cities, economic developed areas are better than poor areas, and water shortage areas are better than areas rich in water resources.

\subsection{Lack of Public Awareness for Participation in River Protection}

In order to realize the public's cognition degree of the river status and river management, we designed and sent out 2000 questionnaires to both Beijing, Tianjin and Nanjing. A total of 1283 valid questionnaires were collected. The questionnaire included some basic questions, such as the primary pollution sources of urban river and which problems face urban rivers (Table 1). According to the survey, $89 \%$ of people think that industrial pollution is the main source of pollution of rivers; $32 \%$ do not realize that domestic pollution has also become the main pollution source of rivers with the progress of urbanization and the increase of population. Ninety-two percent of responders think that the rivers are now facing serious threats, and nearly $80 \%$ of the people think that the most prominent problem is the deterioration of water quality. The findings related to river management show that $69 \%$ of people are not satisfied with the current river management situation and $52 \%$ think that the government needs to raise the level of river management. When it comes to participation, only $8 \%$ of people have been involved in river management supervision. Moreover, only $21 \%$ of people have an understanding of the current river management policy. As the capital, Beijing has significantly higher degree of public participation and awareness of river protection than Tianjin and Nanjing. Because Nanjing is rich in water resources, awareness of water conservation and public participation is the lowest. While most citizens know that urban rivers are under serious threat, they do not know what individuals should do.

As the ultimate consumer, governor and the governed of the urban ecological environment, the public plays an important role in urban river management. In addition, public participation and supervision can also make up for drawbacks in government management. All over the world, the successful experience of river management is calling for more public participation in water affairs [57,58]. The Ontario River, for example, launched the Adopt-A-Stream Project since 1995, aimed at encouraging local people to join ecological restoration activities. Any local community, enterprise, environmental group, school, and family with more than 5 people can apply to become a team and "adopt" a section of the river nearby. However, public participation in environmental protection in China is completely different from the "bottom-up" approach in western countries. Top-down management scheme is being forced upon people, whether in urban planning or river pollution control. Hence, the public awareness of river management is not enough, and they cannot make their position clear to government, seriously hampering the enthusiasm of the public participation. Therefore, how to arouse the enthusiasm of public participation becomes the key to solving problems in river management. 
Table 1. Questionnaire of the public's cognition degree of the river status and river management.

\begin{tabular}{|c|c|}
\hline Problem Attributes & Specific Problem \\
\hline Basic information & $\begin{array}{l}\text { Age } \\
\text { Gender } \\
\text { Profession } \\
\text { Education }\end{array}$ \\
\hline River knowledge & $\begin{array}{l}\text { Do you know the functions of rivers } \\
\text { Are the rivers under threat? } \\
\text { What are the main pollutants in the river } \\
\text { What do you think are the most prominent problems in the river? }\end{array}$ \\
\hline River management & $\begin{array}{l}\text { Are you satisfied with the current management status of rivers? } \\
\text { Does the government need to improve river management } \\
\text { Do you know the current river management policy } \\
\text { What do you think are the most pressing issues in river management }\end{array}$ \\
\hline Participation & $\begin{array}{l}\text { Have you participated in river governance supervision? } \\
\text { Have you participated in the publicity work to protect the river } \\
\text { Are friends around you more involved in river protection? } \\
\text { Do you think it is necessary to participate in river management }\end{array}$ \\
\hline
\end{tabular}

\section{Countermeasures and Suggestions}

Regarding the issues raised in the Section 4: unclear management functions, imperfect planning system, ignore the coordinated development of river functions, imbalance in management level and lack of public awareness for participation in river protection, this study has constructed targeted countermeasures and schemes to strengthen the protection and management of river functions: establish a long-term river management coordination mechanisms, improve the relevant laws and regulations, change development ideas for priority of ecology, take effective economic measures and encourage public participation and strengthen public supervision. In addition, since river management involves the integrated and cross management of water conservancy, transportation, urban construction, land and other departments, it has a huge impact on the actual operation of river management. Therefore, continuous research and a series of measures will be combined to further promote river management.

\subsection{Establish a Long-Term River Management Coordination Mechanisms}

For unclear management function of river systems, river chief system is an innovation of river management, which requires officials at every level of government to take full responsibility for the rivers in regions under their jurisdiction. It was first established in Wuxi City, Jiangsu Province, in order to push anti-pollution efforts. With regard to river management, China has made it a priority to promote river chief system — but how is river managed through the system? Taking Chaoyang District of Beijing as an example, responsibilities are divided based on watershed division and jurisdiction. The river network in this district is compartmentalized into four parts by watershed, including Qinghe-Wenyu River, Ba River, Tonghui River and Xiaotaihou River, and more than 200 rivers are classified according to watershed. More than 600 river chiefs per district, township—or village level—are managing rivers. The division of responsibility system is shown in Figure 8. In the short term, remarkable results have been obtained and water quality is improved. The management system of water resources in many foreign countries has basically undergone a transformation from the decentralized model to the centralized one, so river chief system is an essential stage of river management in China.

Although the work is refined by river chief system, the problems of intersection and interregion river management are still unresolved. The main problem of river management mechanism is the lack of specialized coordinating bodies to link the various departments and regions. We recommend establishing an institution as the link between various departments and regions to take charge of the integrated coordination and be responsible for releasing water quantity. The institution unifies the 
river management work of various departments and establishes a long-term river management system suitable for China's river chief system.

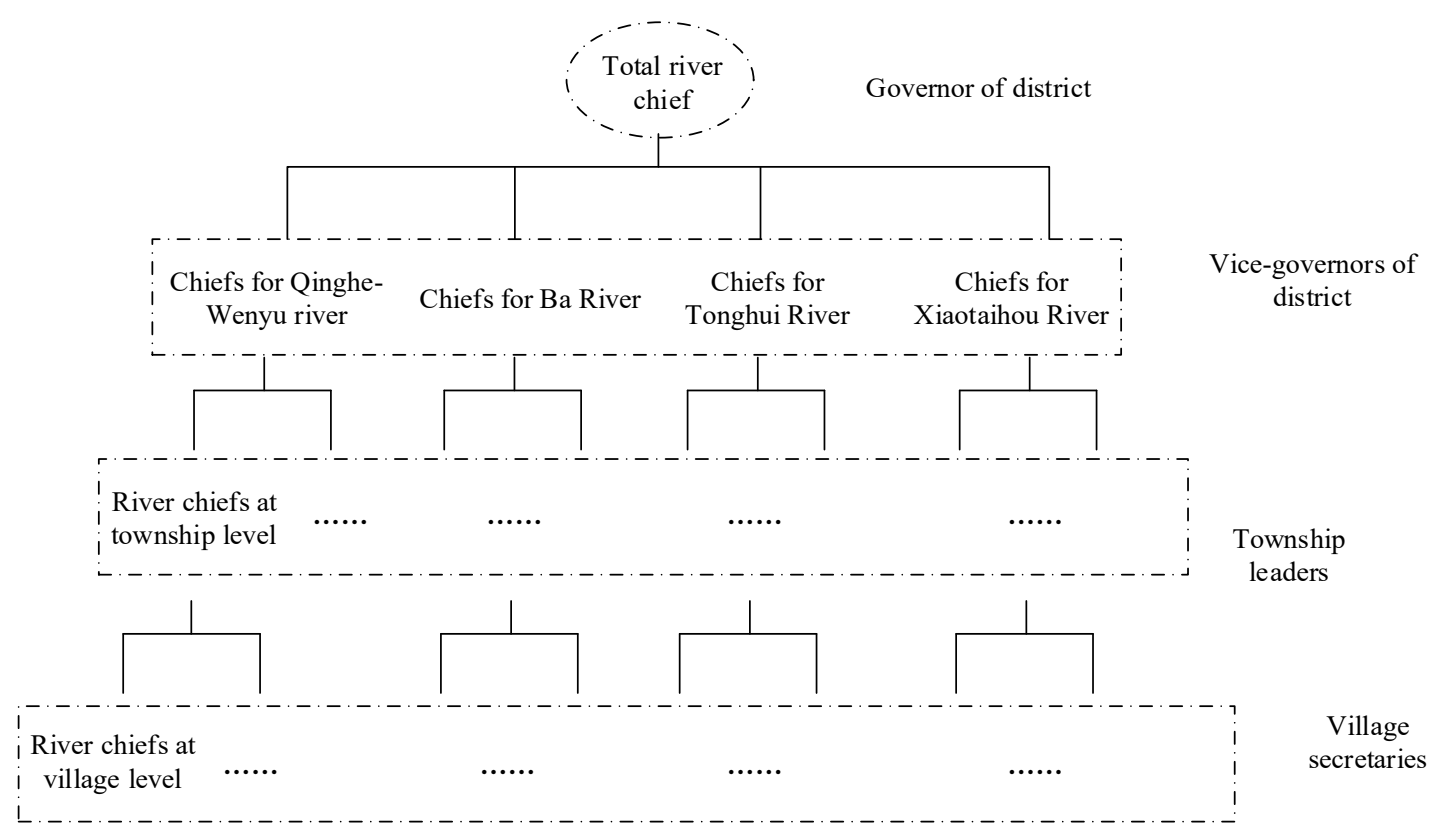

Figure 8. Responsibility division system for river chiefs at different levels in Chaoyang district.

\subsection{Improve the Relevant Laws and Regulations}

For the imperfect planning system, there is only one specialized regulation for river management at state level at present, which refers to regulations of river administration of the People's Republic of China. River harnessing is regulated in this regulation, but there are no specific requirements for the management of power generation, irrigation. In the rapid process of urbanization, people's living standards are constantly improving and demand for power generation, irrigation and other functions of rivers also increase. Although the water conservancy departments of the provinces and cities have made specific provisions based on the actual planning requirements, these provisions apply only to administrative areas. Therefore, some modifications and supplement are necessary. In addition, the regulation have only been amended twice and the contents have hardly changed, so it can no longer meet the needs of river management under the new situation. It is suggested that the experiences and lessons of river management be summed up, and that the regulations be comprehensively revised. It is also necessary to match the requirements of the latest water policies such as the Action Plan for Water pollution Control.

The biggest drawback of the river chief system is relying on the "rule of man", lacking the support of a sound legal system. In the short term, it is indeed possible to strongly promote the "river length system" and achieve immediate results. However, in the long run, there is absolutely no benefit. The river chief policy depends on laws, regulations and technical standards to take the path of virtuous circle management, thus, the further institutionalization of "river chief system" through legislation is the key to the reform and innovation. In the legal system, "river chief", the responsibility of all kinds of river governance subjects, and public participation in supervision should be taken into account. In the process of promoting the river chief system in a general way, it is supported by supporting laws and regulations.

\subsection{Change Development Ideas for Priority of Ecology}

River is an important part of urban ecological civilization, and it is very important to coordinate the relationship between urban development and river protection. With the accelerating process of urbanization, the river facing increasingly affect the urban development. In some cities, local 
governments take the indicator of economic development as the main consideration and carry out economic development activities that are not conducive to the sustainable use of river. The State Council's "Water Pollution Prevention and Control Action Plan" puts forward new development ideas in terms of water resources and environmental carrying capacity based on water resources, cities, land, population and production. Changing the development mode is the key to solving the contradiction between urban development and river protection. The evaluation system of urban development must include not only economic indicators, but also environmental indicators. Xiong'an New area, the newly established national new area, is the part of advancing the coordinated development of the Beijing-Tianjin-Hebei region. In order to improve the its water environment quality, Xiong'an New area is being built into a special zone of ecological civilization at present, which indicates that China attaches great importance to the construction of ecological civilization. The idea of development should be extended to the whole country as soon as possible.

To date, China is promoting the construction of "sponge city". River is an important component of "sponge"; thus, comprehensive management of urban river should be the focal point of "sponge city" construction. Many development opportunities brought by "sponge city" construction should be taken advantage of in river management to improve the ecological environment of urban river and to achieve coordinated development between economy-society and environment.

\subsection{Take Effective Economic Measures}

For the imbalance in management level, green credit and green-bond are good solution. Green credit is an economic mean put forward by the Ministry of Environmental Protection, the People's Bank of China and China banking regulatory commission in order to curb the blind expansion of high-energy and high-pollution industries. When banks approve enterprise loans, the pollution discharge is brought into assessment standards and increase stringent limits on lending for high-energy and high-pollution industries. This policy has a pronounced effect on regularizing enterprise environmental behavior. Green-bond is another economic policy, which differs from green credit in that it limits pollutant emissions and restrain development of high-pollution industries in terms of capital financing. Green credit and green-bond are effective economic means to control pollution and protect the environment and they should be vigorously promoted in river management. Enterprises environmental behavior should be regulated through green economic means, especially for high-pollution and high-emission enterprises, such as paper mill and steel plant, to curb polluting investment and reduce pollutants emissions fundamentally.

In addition, political and financial support should also be given to environmental and low-pollution enterprises. Since January 2018, China has been changing the charge for disposing pollutants into environmental tax. According to estimates from the Central University of Finance and Economics, the annual environmental tax can reach 50 billion yuan. However, China intends to unify this fund into national financial budget, which may not be conducive to the investment of protecting environment. The income from environmental tax should be earmarked for environmental protection, river protection, low-pollution enterprises and develop new technologies. Facing increasingly serious pollution problems, environmental protection work attracts national attention. Since 2006, China's total investment in treatment of environmental pollution generally shows a steady growth trend, but in recent years, the ratio to GDP was slightly lower. There is a gap between the improvement of water quality of urban river actually made and the expected target, and the lack of investment for water pollution prevention is the main reason. In 2016, the issue that the proportion of investment in environmental protection to GDP cannot be less than 3.5\% (Figure 9). It is not enough to increase the investment only relying on the government, society capital should be guided to participate in water management. 


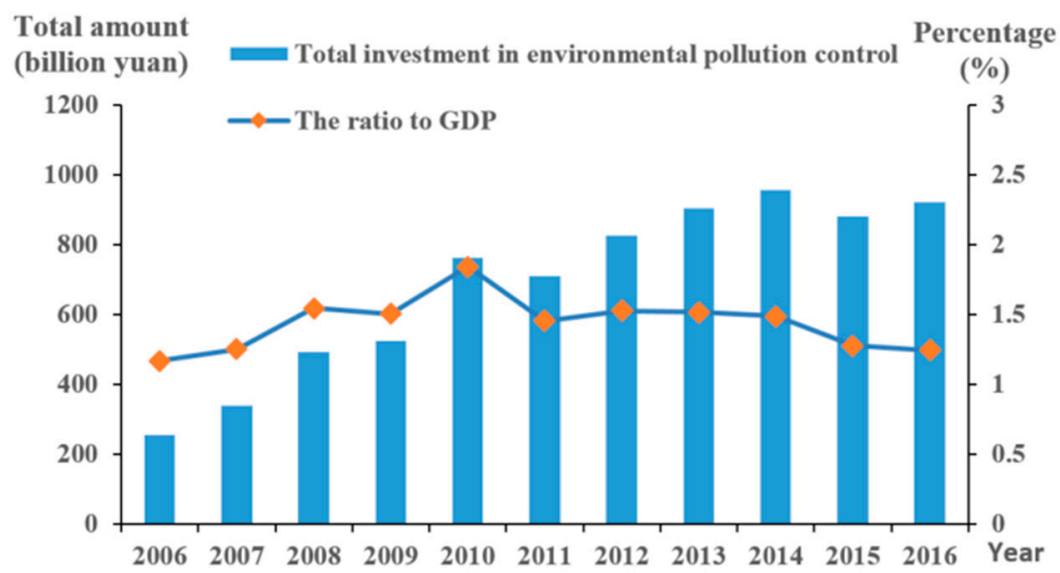

Figure 9. Total investment in environmental pollution control.

Public-private partnership (PPP) is a new mode of investment and financing to encourage private enterprises and private capital to cooperate with government $[59,60]$, which can effectively solve the problem of insufficient investment in river management. Therefore, the government needs to open up the water market to social capital and promote PPP model in river management, which cannot only can ease the financial pressure on local governments, but also can ensure the investment of river improvement.

\subsection{Encourage Public Participation and Strengthen Public Supervision}

Based on the lack of public awareness in river protection, China's Ministry of Housing and Urban-Rural Development and the Ministry of Environmental Protection have launched an information publishing platform for releasing water quality data of malodorous and black river, and a WeChat official account has been set up in the meantime to release the list of malodorous and black rivers. However, the level of public participation is low. On one hand-as a vulnerable group-much of the public does not dare to voice in these government-led reporting platforms. On the other hand-because some of the public awareness of environmental protection is not strong-they feel irrelevant about the work of environmental protection.

In order to empower the public play a bigger role in water protection and management, efforts should be made to cultivate public participation awareness and improve public participation capacity. Specifically, on one hand, the Ministry of Environmental Protection should expand publicity regarding river protection and related laws and regulations with opportunity offered by World Water Day and other activities. On the other hand, public opinions should be sought for the formulation and revision of river laws and regulations. Only through public participation in river management can a series of problems urban river facing in China be solved fundamentally. It should take advantage of Chinese political system and unites public strength and government strength to participate in river management.

\section{Conclusions}

In the rapid process of urbanization in China, the degradation of river function is becoming increasing serious, which is bringing great pressure on the sustainable utilization of rivers and further restricts the healthy development of cities. China is still in an accelerating period of urbanization; the impact of urbanization on the river will increase, and the task of river protection and management will be more onerous. In the face of a more serious situation in the future, China should raise the standard of river management from the aspects of management mechanism, economic incentives, technical support, change the concept of development. To realize the coordinated development of urbanization and river utilization, China still has a long way to go. The government and the public 
must first attach importance to river management and regard river protection as a primary task of the sustainable development of the city.

Author Contributions: Z.Z. contributed substantially to conceptualization, methodology, validation, data curation, data interpretation and writing. All author participate in drafting the article or revising it critically and give final approval of the version to be submitted. All authors have read and agreed to the published version of the manuscript.

Funding: This research was supported by the National Key Research and Development Program of China (2019YFC0408902), the National Natural Science Foundation of China (Grant No. 51879010 and 51479003), the Graduate Innovation Fund in Beijing Key Laboratory of Urban Hydrological Cycle and Sponge City Technology (HYD2020IFDC03) and the 111 Project (Grant No. B18006).

Acknowledgments: The authors thank the editors and anonymous reviewers for suggesting the constructive comments and corrections that substantially improved the quality of the study.

Conflicts of Interest: The authors declare no conflicts of interest.

\section{References}

1. Ministry, W.R.; National Bureau, S. Bulletin of First National Census for Water; China Water Resources \& Hydropower Press: Beijing, China, 2013.

2. Deng, X.; Xu, Y.; Han, L.; Yu, Z.; Yang, M.; Pan, G. Assessment of river health based on an improved entropy-based fuzzy matter-element model in the Taihu Plain, China. Ecol. Indic. 2015, 57, 85-95. [CrossRef]

3. Baschak, L.; Brown, R. An Ecological Framework for the Planning, Design and Management of Urban River Greenways. Landsc. Urban Plan. 1995, 33, 211-225. [CrossRef]

4. Rawson, M. Urban Rivers: Remaking Rivers, Cities, and Space in Europe and North America. Environ. Hist. 2013, 18, 642-644. [CrossRef]

5. Poulard, C.; Lafont, M.; Lenar-Matyas, A.; Lapuszek, M. Flood mitigation designs with respect to river ecosystem functions-A problem oriented conceptual approach. Ecol. Eng. 2010, 36, 69-77. [CrossRef]

6. Su, S.; Li, D.; Zhang, Q.; Xiao, R.; Huang, F.; Wu, J. Temporal trend and source apportionment of water pollution in different functional zones of Qiantang River, China. Water Res. 2011, 45, 1781-1795. [CrossRef]

7. Zhang, K.H.; Song, S.F. Rural-urban migration and urbanization in China: Evidence from time-series and cross-section analyses. China Econ. Rev. 2003, 14, 386-400. [CrossRef]

8. Chuanglin, F.; Xueqin, L. The eco-environmental guarantee for China's urbanization process. J. Geogr. Sci. 2009, 19, 95-106. [CrossRef]

9. Huang, J.; Lu, X.X.; Sellers, J.M. A global comparative analysis of urban form: Applying spatial metrics and remote sensing. Landsc. Urban Plan. 2007, 82, 184-197. [CrossRef]

10. Paul, M.J.; Meyer, J.L. Streams in the urban landscape. Annu. Rev. Ecol. Syst. 2001, 32, 333-365. [CrossRef]

11. Bolognesi, T. The water vulnerability of metro and megacities: An investigation of structural determinants. Nat. Resour. Forum 2014, 39, 123-133. [CrossRef]

12. Visser, H.; Bouwman, A.; Ligtvoet, W.; Petersen, A.C. A Statistical Study of Weather-Related Disasters: Past, Present and Future; Netherlands Environmental Assessment Agency PBL: Den Haag, The Netherlands, 2012.

13. Zhao, Z.; Wang, H.; Bai, Q.; Wu, Y.; Wang, C. Quantitative Analysis of the Effects of Natural and Human Factors on a Hydrological System in Zhangweinan Canal Basin. Water 2020, 12, 1864. [CrossRef]

14. Zhao, Z.; Wang, H.; Wang, C.; Li, W.; Chen, H.; Deng, C. Changes in reference evapotranspiration over Northwest China from 1957 to 2018: Variation characteristics, cause analysis and relationships with atmospheric circulation. Agric. Water Manag. 2020, 231, 105958. [CrossRef]

15. Deng, C.; Wang, H.; Gong, S.; Zhang, J.; Yang, B.; Zhao, Z. Effects of urbanization on food-energy-water systems in mega-urban regions: A case study of the Bohai MUR, China. Environ. Res. Lett. 2020, 15, 044014. [CrossRef]

16. Antrop, M. Landscape change and the urbanization process in Europe. Landsc. Urban Plan. 2004, 67, 9-26. [CrossRef]

17. Guangzhong, C.; Xue, B.; Tao, L. Comprehensive evaluation of the urbanization level in Yangtze River Delta Region: An index framework based on the population, economic structure and land use. Geogr. Res. 2011, 30, 2139-2149. 
18. Zhang, D.; Xu, J.; Zhang, Y.; Wang, J.; He, S.; Zhou, X. Study on sustainable urbanization literature based on Web of Science, scopus, and China national knowledge infrastructure: A scientometric analysis in CiteSpace. J. Clean Prod. 2020, 264, 121537. [CrossRef]

19. Yu, A.T.W.; Wu, Y.; Shen, J.; Zhang, X.; Shen, L.; Shan, L. The key causes of urban-rural conflict in China. Habitat Int. 2015, 49, 65-73. [CrossRef]

20. Gregory, K.; Davis, R.; Downs, P. Identification of River Channel Change to Due to Urbanization. Appl. Geogr. 1992, 12, 299-318. [CrossRef]

21. Wen, Y.; James, P.; Kai, Y. Impact of Urbanization on Structure and Function of River System-Case Study of Shanghai, China. Chin. Geogr. Sci. 2006, 16, 102-108. [CrossRef]

22. Ren, L.; Cui, E.; Sun, H. Temporal and spatial variations in the relationship between urbanization and water quality. Environ. Sci. Pollut. Res. 2014, 21, 13646-13655. [CrossRef]

23. Goel, P.; Saxena, A.; Sen Singh, D.; Verma, D. Impact of rapid urbanization on water quality index in groundwater fed Gomati River, Lucknow, India. Curr. Sci. 2018, 114, 650-654. [CrossRef]

24. Qiong, X.; Hongrui, W.; Changshun, L.; Yuanyuan, G. Problems in River Use and Management during the Rapid Urbanization Process and the Strategies. Resour. Sci. 2012, 34, 424-432.

25. Yinjun, Z.; Aizhong, D.; Fuxin, S.; Kaimei, W. On Theory of River Function. J. Beijing Norm. Univ. Nat. Sci. 2013, 49, 68-74.

26. Hanley, N.; Wright, R.E.; Alvarez-Farizo, B. Estimating the economic value of improvements in river ecology using choice experiments: An application to the water framework directive. J. Environ. Manag. 2006, 78, 183-193. [CrossRef] [PubMed]

27. Sear, D.A.; Newson, M.D. Environmental change in river channels: A neglected element. Towards geomorphological typologies, standards and monitoring. Sci. Total Environ. 2003, 310, 17-23. [CrossRef]

28. Deng, X.; Xu, Y.; Han, L.; Song, S.; Yang, L.; Li, G.; Wang, Y. Impacts of Urbanization on River Systems in the Taihu Region, China. Water 2015, 7, 1340-1358. [CrossRef]

29. Kai, Y.; Wen, Y.; Jun, Z.; Shiyuan, X. Stream Structure Characteristics and Its Urbanization Responses to Tidal River System. Acta Geogr. Sin. 2004, 59, 557-564.

30. Ministry, E.P. China Environmental State Bulletin; China Statistics Press: Beijing, China, 2016.

31. Mittal, N.; Bhave, A.G.; Mishra, A.; Singh, R. Impact of Human Intervention and Climate Change on Natural Flow Regime. Water Resour. Manag. 2016, 30, 685-699. [CrossRef]

32. Yi, X.Y. The Regulation Strategy for Wandering Reach of Zhang River. In Progress in Industrial and Civil Engineering Ii, Pts 1-4; Yang, W., Liang, J., Eds.; Trans Tech Publications Ltd.: Durnten-Zurich, Switzerland, 2013; Volume 405-408, pp. 2068-2071. ISBN 978-3-03785-857-8.

33. Changzhi, L.; Zhaoyin, W.; Baosheng, W.; Jing, Z. Impacts of descending Tongguan elevation on fluvial process in the Weihe River. J. Sediment Res. 2005, 4, 45-53.

34. Wu, X.; Wang, H.; Bi, N.; Nittrouer, J.A.; Xu, J.; Cong, S.; Carlson, B.; Lu, T.; Li, Z. Evolution of a tide-dominated abandoned channel: A case of the abandoned Qingshuigou course, Yellow River. Mar. Geol. 2020, 422, 106116. [CrossRef]

35. Pagliaro, M.D.; Knouft, J.H. Differential effects of the urban heat island on thermal responses of freshwater fishes from unmanaged and managed systems. Sci. Total Environ. 2020, 723, 138084. [CrossRef] [PubMed]

36. Knouft, J.H.; Ficklin, D.L. The potential impacts of climate change on biodiversity in flowing freshwater systems. Annu. Rev. Ecol. Evol. Syst. 2017, 48, 111-133. [CrossRef]

37. Lin, Y.; Liu, A.; Ma, E.; Li, X.; Shi, Q. Impacts of future urban expansion on regional climate in the Northeast Megalopolis, USA. Adv. Meteorol. 2013, 2013, 362925. [CrossRef]

38. Yu, Z.; Yao, Y.; Yang, G.; Wang, X.; Vejre, H. Spatiotemporal patterns and characteristics of remotely sensed region heat islands during the rapid urbanization (1995-2015) of Southern China. Sci. Total Environ. 2019, 674, 242-254. [CrossRef] [PubMed]

39. Gaudard, A.; Weber, C.; Alexander, T.J.; Hunziker, S.; Schmid, M. Impacts of using lakes and rivers for extraction and disposal of heat. Wiley Interdiscip. Rev. Water 2018, 5, e1295. [CrossRef]

40. Milly, P.C.; Dunne, K.A.; Vecchia, A.V. Global pattern of trends in streamflow and water availability in a changing climate. Nature 2005, 438, 347-350. [CrossRef]

41. Bunn, S.E.; Arthington, A.H. Basic principles and ecological consequences of altered flow regimes for aquatic biodiversity. Environ. Manag. 2002, 30, 492-507. [CrossRef] 
42. Dajun, S.; Guna, A.; Chen, C. Water rights system in the Yellow River Basin: Problems, challenges, and suggestions. Resour. Sci. 2020, 42, 46-56.

43. Yaobin, L.; Hongmei, C. The evolution, problems and protecting suggestions of lakes in Wuhan municipality. J. Hubei Univ.Nat. Sci. Ed. 2003, 25, 163-167.

44. Linhua, L.; Ling, L.; Qiyun, Z. Discussion on Water Resources Utilization and Ecological Protection in the Yellow River Delta; Shang, H.Q., Luo, X.X., Eds.; Yellow River Conservancy Press: Zhengzhou, China, 2007; pp. 175-180. ISBN 978-7-80734-296-0.

45. Song, J.; An, D.; Anderson, B. A Survey of Current Drinking Water Supply for Shanghai. In Environment Materials and Environment Management Pts 1-3; Du, Z.Y., Sun, X.B., Eds.; Trans Tech Publications Ltd.: Durnten-Zurich, Switzerland, 2010; Volume 113-116, p. 68. ISBN 978-0-87849-259-6.

46. Dajun, S.; Hao, W.; Yunzhong, J. Riverbasin management organization: An international comparison and suggestions on China. J. Nat. Resour. 2004, 19, 86-95.

47. Hu, D.-S.; Sun, R.-H.; Xu, S.-Q. Enlightenment from international water law and its values to the legislation on the Yangtze River Basin. J. Nat. Resour. 2020, 35, 425-437.

48. Tosun, J.; Lang, A. Policy integration: Mapping the different concepts. Policy Stud. 2017, 38, 553-570. [CrossRef]

49. Jordan, A.; Lenschow, A. Environmental policy integration: A state of the art review. Environ. Policy Gov. 2010, 20, 147-158. [CrossRef]

50. Wang, Y.; Yang, J.; Chang, J. Development of a coupled quantity-quality-environment water allocation model applying the optimization-simulation method. J. Clean Prod. 2019, 213, 944-955. [CrossRef]

51. Han, Q.; Huang, X.; Xing, Q.; Shi, P. A review of environment problems in the coastal sea of South China. Aquat. Ecosyst. Health Manag. 2012, 15, 108-117. [CrossRef]

52. Tao, T.; Tao, X.; Linsen, W.; Hexiang, Y. Multi-objective Optimization Design of Lowimpact Development Plan in Sponge City Construction. J. Tongji Univ. Nat. Sci. 2019, 47, 92-96.

53. Jia, H.; Yu, S.L.; Qin, H. Low Impact Development and Sponge City Construction for Urban Stormwater Management Selected Papers from the 2016 International Low Impact Development Conference in Beijing, China PREFACE. Front. Env. Sci. Eng. 2017, 11, 20. [CrossRef]

54. Jianlong, W.; Wu, C. Low Impact Development and Green Building. China Water Wastewater 2011, $27,17-20$.

55. Weizhen, T.; Xinxin, R.; Nian, D.; A, P.M. Design of Rainwater System with Low Impact Development for Municipal Road Based on SWMM Model. China Water Wastewater 2016, 32, 109-112.

56. Yuan, Z.; Liang, C.; Dingqiang, L.I. Progress and Prospect of the Study on Sponge City in China. Ecol. Environ. Sci. 2017.

57. Buijs, A.E. Public support for river restoration. A mixed-method study into local residents' support for and framing of river management and ecological restoration in the Dutch floodplains. J. Environ. Manag. 2009, 90, 2680-2689. [CrossRef] [PubMed]

58. Mann, K.B.; Berry, K.A.; Bassett, S.; Chandra, S. Voting on Floodplain Conservation: The Role of Public Values and Interactions along the Carson River, Nevada. Soc. Nat. Resour. 2013, 26, 568-585. [CrossRef]

59. Cheung, E.; Chan, A.P.C. Risk Factors of Public-Private Partnership Projects in China: Comparison between the Water, Power, and Transportation Sectors. J. Urban Plan. Dev 2011, 137, 409-415. [CrossRef]

60. Wu, X.; House, R.S.; Peri, R. Public-private partnerships (PPPs) in water and sanitation in India: Lessons from China. Water Policy 2016, 18, 153-176. [CrossRef]

(C) 2020 by the authors. Licensee MDPI, Basel, Switzerland. This article is an open access article distributed under the terms and conditions of the Creative Commons Attribution (CC BY) license (http://creativecommons.org/licenses/by/4.0/). 